\title{
A Büntetés-végrehajtási Szervezet fegyveres biztonsági örsége
}

\section{LIPPAI Zsolt ${ }^{1 \oplus}$}

\begin{abstract}
A fegyveres biztonsági őrség és annak jogelöd szervezetei közel egy évszázados múltra tekinthetnek vissza. Ez hazánk egyetlen olyan sajátos fegyveres szervezete, amely sem a rendészeti szervekhez, sem pedig a honvédséghez nem tartozik, jellege polgári, mégis szigorúan hierarchikus és ellenőrzött szabályok között végzi tevékenységét. Rendszereken átivelö funkciója, küldetése pedig, amiért létrehozták, változatlan. Napjainkban, a közel 7000 fö összlétszámú FBÖ látja el az állam müködése, illetöleg a lakosság ellátása szempontjából kiemelkedően fontos tevékenységek, létesitmények, szállitmányok védelemét.

A fegyveres biztonsági őrséget és jogelőd szervezeteit tanulmányozva állapítható meg, hogy míg nemzetközi és hazai viszonylatban számos kutatás foglalkozik a kritikus infrastruktúra-védelem történetiségével, addig a hazai szervezeti elözmények történeti feldolgozása még nem valósult meg. Tanulmányomban, hiánypótló alkotásként, a büntetés-végrehajtás fegyveres biztonsági őrségének létrejöttét és jelenkori müködését mutatom be.
\end{abstract}

Kulcsszavak: Büntetés-végrehajtási Szervezet, fegyveres biztonsági őrség

\section{Bevezetés}

A fegyveres biztonsági őrség (FBŐ) és annak jogelőd szervezetei - az üzemőrség, az iparőrség és a polgári fegyveres őrség - közel egy évszázados múltra tekinthetnek vissza. Ez hazánk egyetlen olyan sajátos fegyveres szervezete, amely sem a rendészeti szervekhez, sem pedig a honvédséghez nem tartozik, jellege polgári, mégis szigorúan hierarchikus és ellenőrzött szabályok között végzi napi szolgálati tevékenységét. Viszontagságokkal gazdagított története során számos változáson ment keresztül, ennek ellenére létezik, stabilan múködik, és tevékenységére még hosszú távú szükség mutatkozik. Rendszereken átívelő funkciója, küldetése, amiért létrehozták, változatlan. ${ }^{2}$ Napjainkban, a közel 7000 fő összlétszámú - amelyből a Büntetés-végrehajtási Szervezet FBŐ őrségének állománytábla szerinti létszáma

\footnotetext{
Lippai Zsolt rendőr alezredes, Nemzeti Közszolgálati Egyetem Rendészettudományi Kar Magánbiztonsági és Önkormányzati Rendészeti Tanszék, mesteroktató, Nemzeti Közszolgálati Egyetem Rendészettudományi Doktori Iskola, doktori hallgató.

Zsolt Lippai, Police Lieutenant Colonel, University of Public Service, Faculty of Law Enforcement, Department of Private Security and Local Governmental Law Enforcement Assistant Lecturer, Doctoral School of Police Sciences and Law Enforcement, PhD student. E-mail: lippai.zsolt@uni-nke.hu

2. Az FBÖ múltja. Forrás: https://mfbosze.hu/az-fbo-multja/
} 
43 objektumban 411 fő ${ }^{3}$ - FBŐ látja el az állam müködése, illetőleg a lakosság ellátása szempontjából kiemelkedően fontos tevékenységek, létesítmények, szállítmányok $^{4}$ (létfontosságú vagy kritikus infrastruktúra), törvényben ${ }^{5}$ és belügyminiszteri rendeletben ${ }^{6}$ szabályozott védelemét. ${ }^{7}$

Tanulmányomban a Büntetés-végrehajtási (Bv.) Szervezet országos parancsnokának írásbeli engedélye alapján elvégzett hiánypótló kutatásom eredményeként a Bv. FBŐ létrejöttét és jelenkori működését mutatom be.

\section{A Büntetés-végrehajtási Szervezet}

A büntető igazságszolgáltatás az államalapítás óta rendelkezik kutatható írásos anyagokkal, hiszen a törvények megjelenése óta létezik a Bv., írásbeli emlékek alapján pedig a 11. századtól beszélhetünk börtönbüntetésről. ${ }^{8}$ A jogszabályokban és okleveles forrásanyagokban fennmaradt börtönre használatos kifejezésként említhetjük a tömlöc (temlec), karcer (carcer), börtön (berten), az áristom (arestum, árestom), a fogság (detentio, captivatio, ergastulum) elnevezéseket, amelyek mind a bezárás, a szabadságelvonás valamely változatát jelentették. ${ }^{9}$ A Rendészettudományi szaklexikon ${ }^{10}$ megfogalmazásában pedig a Bv. az igazságszolgáltatás rendszeréhez kapcsolódó olyan végrehajtó állami és fegyveres rendvédelmi szervezet, amely alapvetően a külön törvényben meghatározott szabadságelvonással járó büntetések, intézkedések, büntetőeljárási kényszerintézkedések megvalósítására, a szabadságvesztésből szabadultak utógondozására, valamint a büntetés-végrehajtási pártfogó felügyelői feladatok végrehajtására hivatott. ${ }^{11}$

A Börtönstatisztikai Szemle 2019. december 31. szerinti időszaki statisztikáját alapul véve a közel 18 ezer fő fogvatartott ${ }^{12}$ őzését ellátó testület középirányító szerve az Országos Parancsnokság (BVOP), amely alá 30 Bv. intézet, tíz gazdasági társaság, illetve négy intézmény - a Bv. Oktatási, Továbbképzési és Rehabilitációs Központja, a Nemzeti Közszolgálati Egyetem Rendészettudományi Kar Bv.-i Tanszéke, a Bv. Egészségügyi Központ, illetve az Igazságügyi Megfigyelő és Elmegyógyító Intézet - tartozik. Az első három intézmény a személyi állomány képzésére

\footnotetext{
A BVOP által biztosított 2021. 03. 21-ei állapotnak megfelelő statisztikai adatok alapján.

A Bv. FBŐ jelenleg még a szállítmányok védelmét nem látja el, a megfogalmazás az FBŐ törvényben meghatározott feladatait jelöli.

1997. évi CLIX. törvény a fegyveres biztonsági őrségről, a természetvédelmi és a mezei őrszolgálatról. 27/1998. (VI. 10.) BM rendelet a fegyveres biztonsági őrség Mủködési és Szolgálati Szabályzatának kiadásáról.

Lippai Zsolt: Az elmosódó határvonalak margójára. Szakmai Szemle, 21. (2021), 1. 157.

Várkonyi Zsolt Kristóf (főszerk.): Ezer éves múltunk. A büntetés-végrehajtás az igazság védelmében. Budapest, BVOP, 2021. 10.

9 Lőrincz József - Mezey Barna: A magyar börtönügy története. Budapest, Dialóg Campus, 2019. 32.

10 Boda József (szerk.): Rendészettudományi Szaklexikon. Budapest, Dialóg Campus, 2019.

11 Boda (szerk.) (2019): i . m. 89.

12 Várkonyi Zsolt Kristóf (főszerk.): Börtönstatisztikai Szemle, 2020. 4.
} 
szolgál, míg a két egészségügyi intézmény a fogvatartottak ellátását biztosítja. Személyi állományának létszáma meghaladja a 8000 főt. ${ }^{13}$

\section{Hazánk legifjabb fegyveres biztonsági őrségének létrehozása}

2019. március 01. kezdettel a Bv. szerv vezetőjének írásbeli kezdeményezésére, az Országos Rendőr-főkapitányság (ORFK) által meghozott őrzést elrendelő határozat alapján 21 fős Bv. FBÖ - harmadfokú állandó őrségként ${ }^{14}$ - kezdte meg szolgálatát a Kiskunhalasi Országos Bv. Intézetben. A 2019. október 01-jén (32 objektumban 191 fő) ${ }^{15}$, majd 2020. február 01-jén ${ }^{16}$ - szintén a BVOP kezdeményezésére - megvalósuló létszámfejlesztéssel őrzendő objektumok száma 35-re, az FBŐ létszáma pedig 270 főre, így a harmadfokú állandó őrség rendszeresített létszáma, az őrségparancsnokkal együtt 271 före növekedett. Az újabb létszámbeli változást 2020. május 01-jétől a könnyűszerkezetes férőhelybővítés megvalósítása és újabb objektumok őrzésbe vonása jelentette, amikor az FBŐ állománytábla szerinti létszáma a jelenleg rendszeresített 411 före emelkedett. ${ }^{17}$

ORFK határozat alapján a Bv. szervezetében létrehozott ${ }^{18}$ FBŐ tagja, törvényi felhatalmazás alapján közremüködhet a területére történő be- és kiléptetés, az objektumvédelmi, járőrözési tevékenység, területőrzés végrehajtásában a Bv. szervek határán kívül elhelyezkedő területen annak anyagi javainak vagy az ott-tartózkodó fogvatartottak őrzése érdekében, illetőleg a fogvatartotti foglalkoztatás biztosításában a Bv. szervek területén belül vagy kívül. ${ }^{19} \mathrm{Az}$ őrzésben érintett $\mathrm{Bv}$. szervek - a felsorolt szolgálati feladatokból - jellemzően a területükre történő beés kiléptetési tevékenység végzésére, ritkábban pedig objektumvédelmi és járőrözési feladatokra alkalmazzák az FBŐ állományát. A szolgálati feladatok ellátásának rendjét a hatályos jogszabályi elvárásoknak megfelelően a Bv. szerv munkatársai által elkészített és az ORFK által jóváhagyott őrszolgálati dokumentumok (őrségutasítás, őrutasítás) szabályozzák.

A Bv. szervezet történetében rendhagyóan újnak számító szervezeti elem létrehozásakor azonban számos prognosztizálható, illetőleg csak a későbbeikben, a működés megkezdésekor realizálódó nehézséggel kellett az FBŐ jelenkori történetének legifabb őrségeként is nevezhető szervezet vezetőjének szembenéznie. Értve ez alatt az őrök toborzását, felszerelését, képzését, az új munkatársak tevékenységének a Bv. szerv működésébe történő zökkenőmentes beilleszkedését, az őrök szolgálatellá-

\footnotetext{
Büntetés-végrehajtás. Az igazság védelmében. BV szervezet.

4 Harmadfokú ôrség az, amelynek egy-három felállítási helye (járőrútvonala) van.

Az ORFK 29000/2604-43/2019. ált. számú országos elrendelő határozatával.

Az ORFK 29000/2604-66/2019. ált. számú határozatával.

Az ORFK 29000/2464-75/2019. ált. számú határozatával.

18 A rendőrségi határozat kötelezettje az FBŐ-t saját szervezetében (gazdálkodó szervezet vagy költségvetési szerv útján) köteles létrehozni, működtetni, fenntartani, vagy az őrzést más FBŐ-vel rendelkező szerv útján biztosítani.

19 A büntetés-végrehajtási szervezetről szóló 1995. évi CVII. törvény 10. § (3a) bekezdése alapján.
} 
tásának testületen belüli elfogadtatását és szakmai jelentőségének megértetését, valamint a fluktuáció okozta létszámhiány folyamatos pótlását, amely témakörökkel a továbbiakban részletesen foglalkozom.

\section{A Bv. FBő irányítása és szervezete}

A Bv. FBŐ működése feletti rendészeti felügyeletet - az ORFK irányításával - a területileg illetékes megyei rendőr-főkapitányságok, míg a szakmai felügyeletet az országos parancsnok biztonsági és fogva tartási helyettese, a múködés szakmai irányítását a BVOP Biztonsági Szolgálata látja el. A tevékenység irányítását pedig az országos parancsnok biztonsági és fogva tartási helyettese, a BVOP Biztonsági Főosztály vezetője, illetőleg az illetékes őrségparancsnokok és őrségparancsnok-helyettesek látják el. ${ }^{20}$

Az őrségparancsnok a Munka Törvénykönyve ${ }^{21}$ hatálya alá tartozó - és a teljes Bv. FBŐ állománnyal kapcsolatos elöljárói teendőket ellátó - munkavállaló, aki felett a munkáltatói jogokat az országos parancsnok gyakorolja, míg szolgálati feladatait a BVOP Biztonsági Szolgálatánál teljesíti. További feladata a BVOP központi objektumaiban szolgálatot teljesítő FBŐ állomány közvetlen irányítása (szolgálatszervezés, ellenőrzés stb.), helyettesítését az őrségparancsnok-helyettes(ek) - az adott Bv. szerv Biztonsági Osztályának vezetője - látják el. A helyettes(ek) feladata az érintett Bv. szerv vonatkozásában az FBŐ állomány tevékenységének koordinálása, szakmai irányítása és ellenőrzése. ${ }^{22} \mathrm{Az}$ őrparancsnok(ok) feladat- és hatáskörébe tartozik az FBÖ-állománnyal kapcsolatos napi szintű feladatok ellátása, a szolgálati tevékenység közvetlen irányítása, az eligazítás, ellenőrzés és beszámoltatás végrehajtása. Ugyanakkor a fegyveres biztonsági őr mint a tevékenység ellátásának alapeleme szintén a Munka Törvénykönyvének hatálya alá tartozó, szolgálati lőfegyverrel és meghatározott kényszerítő eszközökkel ${ }^{23}$ őrzési tevékenységet ellátó személy. ${ }^{24}$

\footnotetext{
1/2020. (II. 21.) BVOP utasítás a büntetés-végrehajtási szervezetben működtetett fegyveres biztonsági őrségről 1-5. pont.

21 2012. évi I. törvény a Munka Törvénykönyvéről.

22 Az egyes őrzött objektumokban a szétszórt diszlokáció miatt az őrségparancsnok feladatait az őrségparancsnok-helyettesi feladatokkal megbízott biztonsági osztályvezetők látják el.

${ }^{23}$ A fegyveres biztonsági őr a fegyveres biztonsági őrségről, a természetvédelmi és a mezei őrszolgálatról szóló 1997. évi CLIX. törvény és a fegyveres biztonsági őrség Működési és Szolgálati Szabályzatának kiadásáról szóló 27/1998. (VI. 10.) BM rendelet szerint.

24 1/2020. (II. 21.) BVOP utasítás 6-17. pont.
} 


\section{Toborzás, kiválasztás}

A 21. századi, így a hazai rendészeti szerveket érintő egyik legnagyobb problémaként a létszámhiány datálható, különös tekintettel a megfelelő utánpótlás biztosítására, a pályakezdők toborzására, illetőleg a felvételt nyert személyek rendészeti pályán tartására, valamint az elvándorlással kapcsolatos nehézségek humánpolitikai témakörére. ${ }^{25} \mathrm{Nem}$ mentesül ez alól a Bv. sem, ahol az FBŐ-állomány toborzási, utánpótlás biztosítási tevékenységét a Bv. szervek humán szolgálatainak munkatársai végzik változó eredményességgel (a 2020. március 23-ai állapot szerint a 411 fös állománytábla szerinti státuszon 270 fô FBŐ ôr és 1 fő őrségparancsnok ${ }^{26}$ van állományban). ${ }^{27} \mathrm{~A} \mathrm{Bv}$. szervezet toborzási tevékenységéről általánosságban elmondható hogy annak sikerességét jelentősen befolyásolhatja a toborzó Bv. szerv földrajzi elhelyezkedése (értsd, hogy hazánk mely régiójában helyezkedik el), vagy akár a civil szférában évek óta tartó gazdasági növekedés miatt meglévő munkaerő el- vagy felszívó hatás, gondolva itt például a $\mathrm{Bv}$. szervezet állománya részére meghatározott illetményi kategóriákat jelentősen meghaladó mértékű kereseti lehetőségre. A kínált hivatali ${ }^{28}$ vagy I-es számú váltásos szolgálati vagy munkaidőrendszer ${ }^{29}$ sem tekinthető túl vonzónak, ${ }^{30}$ hiszen az utánpótlás egyik lehetséges célcsoportját jelentő személy- és vagyonőrök többnyire a civil szférában meglévő II-es számú váltásos szolgálati idôrendszert ${ }^{31}$ preferálják, amely mellett akár másodállás vállalásával is kiegészíthetik jövedelmüket. Toborzási szempontból kiemelkedő bevonzó és további lényeges állománymegtartó erőt jelenthetne a 24 órás szolgálatellátásra történő átállás, amennyiben azt az adott bv. intézet személyi és szolgálatszervezési feltételei is lehetővé teszik.

A Bv. szervezet - más rendészeti szervekhez hasonló - toborzási tevékenységében hosszú ideig a hagyományosnak tekintendő úgynevezett írott sajtótermékek felületeit, hirdetési rovatait, illetve a szórólapok útján történő népszerüsítést részesítette előnyben. Az utánpótlás biztosításának tervezésében kiaknázatlan lehetôségként volt sokáig jelen a korszerű online hirdetési platformok célzott spektrumú

25 Christián László - Erdős Ákos: Vészharang és jubileum? A rendészeti felsőoktatás kilátásai, a tisztjelöltek toborzásának és életpályára állításának nehézségei. Belügyi Szemle, 68. (2020), 12. 13-14.

26 A BVOP Biztonsági Szolgálat vezetőjétől kapott információ alapján a létszámfeltöltés, pénzügyi fedezet hiányában nem lehetséges.

27 Teremi Zoltán BV FBŐ őrségparancsnokkal a BVOP-n 2021. 03. 23-án készített személyes interjú alapján.

28 A szolgálatteljesítési napok naptári hetenként hétfőtől péntekig tartanak. A heti szolgálatteljesítési idő 40 óra, amelyet hétfőtől csütörtökig 7.30 órától 16.00 óráig, vagy 8.00 órától 16.30 óráig, pénteki munkanapon 7.30 órától 13.30 óráig, vagy 8.00 órától 14.00 óráig terjedő időben kell teljesíteni.

${ }^{29}$ Az I. számú váltásos szolgálati időrendszer váltásonként 12 óra szolgálat 24 óra szabadidő, 12 óra szolgálat 48 óra szabadidő, vagy váltásonként 12 óra szolgálat 12 óra szabadidő, 12 óra szolgálat 48 óra szabadidő, 12 óra szolgálat 12 óra szabadidő, 12 óra szolgálat 72 óra szabadidő.

30 Több Bv. szerv váltásos munkarendben foglalkoztatja az őröket, akár hétvégéken is, tipikusan az I. váltásos rendszernek nevezett módon. Ezek a váltásos rendszerek a hivatásos állományra vonatkozó normák szerinti megnevezések, ugyanakkor a munkavállalóra nem érvényesek. A Munka Törvénykönyve szerinti munkarend például a készenléti jellegú munkakörben teszi lehetővé a 24 órás munkavégzést. Ennek egyedi feltételei teljesülését azonban a munkáltatónak kell vizsgálnia, biztosítania.

31 A II. számú váltásos szolgálati időrendszer váltásonként folyamatos 24 óra szolgálat, 72 óra szabadidő. 
alkalmazása, a hirdetési eredményesség statisztikai figyelésének, értékelésének, annak eredménytelensége esetén pedig az új hirdetési felületek igénybevételének elmaradása, illetőleg a hirdetési szövegek korcsoport-orientált tartalommal való megtöltésének hiánya is. Ezt felismerve, példaértékú és 2020-ban az év honlapjának választott specifikus tartalmú online internetes álláskereső oldalt ${ }^{32}$ alkottak meg, amelyen a szakma iránt érdeklődők valamennyi kérdésükre kimerítő választ kaphatnak. A könnyen használható, interaktív, felhasználóbarát felület bemutatja a Bv. szervezetet, a juttatásokat, a felvételi követelményeket, állásajánlatokat, a jelentkezés folyamatát és kézzelfogható kapcsolatot ajánl az ország területén jelen lévő nagyszámú toborzóirodához. Az álláskereső internetes oldalon megjelentek alapján az FBŐ egyértelműen közölt feladata a Bv. intézet - általam már korábban ismertetett - objektumvédelmi feladataiban való részvétel. A feladat ellátásáért a Bv. szervezet a határozatlan idejű munkaszerződést három hónap próbaidő kikötésével, jogszabály szerinti bejelentett munkabért, cafetériát, útiköltség-elszámolást, formaruházatot (10M e.r. gyakorló öltözet FBŐ karjelvénnyel, felirattal), ingyenes sportolási lehetőséget, fizetett szabadságot és képzés esetén tanulmányi szerződést kínál. ${ }^{33}$ Itt kell még megemlítenem az FBŐ-állomány kényszerítő eszközökkel történő kötelező ellátását, amely maroklőfegyverből, patentbilincsből, vegyi eszközből ${ }^{34}$ és gumibotból áll (a felszerelés témakörével a későbbiekben részletesen foglalkozom).

Az FBÖ-állomány utánpótlási, toborzási tevékenység eredményességének növelése érdekében - vezetői utasításra - a BVOP Biztonsági és Humán Szolgálatai, valamint a szakszervezet képviselőiből munkabizottságot hoztak létre. A bizottság feladata a szolgálati nyugdíjas és a szolgálati járadékra jogosult volt Bv.-s munkatársak FBŐ jogviszonyba bevonási lehetőségét elősegítő feltételek vizsgálata, illetőleg további javaslattétel a megfelelő számú utánpótlás biztosításához szükséges vezetői döntés meghozatalához, a megfelelő hatékonyságú humán stratégia megalkotásához.

A toborzás és kiválasztás témakörénél szükséges megemlítenem a Bv. állományában fegyveres biztonsági őr munkakörben szolgálatot ellátó alkalmazottak Bv. hivatásos állományba történő átvételi lehetőségét is, amely adott esetben még vonzóbbá teheti a munkakörre történő jelentkezést. Az átvételre az egyén saját kérésére, annak vezetői támogatásával, a jelentkező hivatásos szolgálatra történő (fizikai, pszichológiai, egészségügyi stb.) alkalmassága esetén kerülhet sor.

További érdekes - a tanulmányom témájához kapcsolódó, de annak kereteit jelentősen meghaladó - kérdésként jelentkezik a rendészeti szervekhez, így a Bv. szervhez felvételre jelentkezők létszámának hullámzása (jellemzően csökkenése), hazánk demográfiai helyzete és a rendészeti szervek megtartóképességének korlátai, amelyek

\footnotetext{
A Büntetés-végrehajtási Szervezet internetes álláskereső oldala, a https://gyereahuvosre.hu/

Fegyveres biztonsági őr: https://gyereahuvosre.hu/jobs/fegyveres-biztonsagi-or-14/

Érdekességként jegyzem meg hogy a vegyi eszköz megnevezése a Bv. szervezeti törvényében könnygáz.
} 
szintén a jövőbeni humán eredményességi mutatók lehetséges negatív tendenciáit vetíthetik elöre. $^{35}$

\section{Az FBÖ-állomány képzése és oktatása}

Az FBŐ-pozícióra jelentkező, legalább nyolc általános iskolai végzettséggel rendelkező személyek közül kiválasztott, az egészségügyi és pszichológiai alkalmassági vizsgálatokon „alkalmas” minősítést megszerzett személyeket a Bv. szervek állományba veszik portás, telepőr munkakörbe, és a képzésük megkezdéséig úgynevezett gyakorló (tanuló) szolgálatot látnak el munkavállalói jogviszonyban az adott szervnél. Részükre a Bv. szerv - a munkavégzéshez szükséges képesítés megszerzéséig - a szervezethez való tartozást igazoló munkavállalói igazolványt, vagy állandó belépési engedélyt állít ki.

A leendő FBŐ-tagok képzését a Bv. Szervezet Oktatási, Továbbképzési és Rehabilitációs Központjának ${ }^{36}$ (Központ) tanárai, kiképzői a BVOP Biztonsági Szolgálat vezetője által jóváhagyott „Képzési Program”37 alapján, a vizsgára is fordított óraszámmal együtt összesen 138 tanórában, öt modulba ${ }^{38}$ felosztva végzik Budapesten, Miskolcon, Állampusztán, Szegeden és Szombathelyen. A képzés során lehetőséget biztosítanak arra, hogy a hallgató megismerje a Bv. szervezet alapvető tevékenységét, az objektumőrzésre vonatkozó feladatokat, valamint az FBŐ-re vonatkozó, működést és belső rendet szabályozó alapvető jogszabályokat, közjogi szervezetszabályozó eszközöket és belső normákat. ${ }^{39}$

A tanfolyam befejezését követő - a BVOP vezetője által országos parancsnoki (OP) utasításban ${ }^{40}$ is szabályozott ${ }^{41}$ - hatósági vizsgákat a Központ a képzés helye szerint illetékes megyei rendőr-főkapitányságok közreműködésével szervezik meg, amely vizsgabizottság egyik tagja a Bv. szerv mindenkori őrségparancsnoka. A leendő fegyveres biztonsági őr a hatósági vizsga teljesítésével egyidejüleg az OP utasításban meghatározott Bv. alapismereti vizsga teljesítésére is kötelezett, amelynek elsajátítandó tudásanyaga megfelelő szintű szakmai jártasságot, eligazodást biztosít a Bv. különlegesen egyedi és sokak által ismeretlen világába. A fegyveres biztonsági őröket a képesítés megszerzésekor az illetékes megyei rendőr-főkapitányság

\footnotetext{
35 Christián László - Lippai Zsolt: Kakukktojás vagy új rendészeti alappillér. In Csaba Zágon - Zsámbokiné Ficskovszky Ágnes: „Tehetség, szorgalom, hivatás”. Budapest, Magyar Rendészettudományi Társaság Vám- és Pénzügyőri Tagozat, 2021. 17-30.

36 Bővebben: https://bv.gov.hu/hu/intezmenyek/bvszotrk

37 A fegyveres biztonsági őrség Működési és Szolgálati Szabályzata kiadásáról szóló 27/1998. (VI. 10.) BM rendelet mellékleteként kiadott Müködési és Szolgálati Szabályzat 73. §-ában meghatározott tartalommal elkészítve.

38 I. Jogi ismeretek, II. Szakmai ismeretek, III. Önvédelmi ismeretek, IV. Fegyverismeret, V. Büntetés-végrehajtási speciális ismeretek.

39 1/2020. (II. 21.) BVOP utasítás 46. pont.

40 1/2020. (II. 21.) BVOP utasítás.

41 A fegyveres biztonsági ôrség Működési és Szolgálati Szabályzatának kiadásáról szóló 27/1998. (VI. 10.) BM rendelet szerint.
} 
humánigazgatási szolgálatától a Bv. szerv által igényelt FBŐ-igazolvánnyal és jelvénnyel látják el.

Természetesen az FBŐ-állomány képzése ezen a szinten nem áll meg, hiszen a már megszerzett szakmai tudást legalább szinten kell tartani, illetőleg azt a Bv. tevékenységével kapcsolatos jogszabályi és egyéb elvárások tükrében folyamatosan fejleszteni szükséges. Ennek alapján az állomány képzését kétfelé kell választani, amelynek egyik eleme a jogszabályi kötelmen alapuló egy- vagy kétévenkénti, ismétlődő képzések, míg a másik eleme a Bv. szerv vezetője által központilag elrendelt évenkénti továbbképzések egymásra épülő rendszere.

Jogszabályi kötelezés alapján az adott Bv. szerv vezetőjének felelősségi körébe tartozó évenkénti lőgyakorlatot kell megszervezni és végrehajtani az FBŐ tagja lőkészségének szinten tartása érdekében. A szolgálatellátáshoz az FBŐ részére rendszeresített lőfegyverrel végrehajtott - amelyen jelen van az FBŐ felügyeletét ellátó megyei rendőr-főkapitányság képviselője is - lőgyakorlat eredményét és annak teljesítését értékelő lapon és haladási naplóban is rögzíteni kell. Az FBŐ-s elméleti ismeretszintjét kétévente a rendőrség és a Bv. képviselőiből álló bizottság ellenőrzi. $\mathrm{Az}$ időszakos, illetve szinten tartó oktatások és képzések megvalósítását az e célra rendszeresített haladási naplóban dokumentálják.

A - 2020-ban először elkészített, majd - 2021-ben már megújított tartalommal kiadott képzési terv havi bontásban tartalmazza az FBŐ részére átadandó elméleti és gyakorlati ismereteket. ${ }^{42} \mathrm{Az}$ elméleti képzéseket 3-5 tanóra, míg a gyakorlati képzéseket 4-6 tanóra időtartamban tervezi és hajtja végre az adott Bv. szerv vezetője. Azok végrehajtásáról minden esetben a BVOP-nak felterjesztett összefoglaló jelentés készül.

Itt kell megemlítenem a teljes FBŐ-állományt érintő - munkatervben meghatározott - érzékenyítés állományvédelmi oktatás keretében történő lebonyolítását, a Nemzeti Védelmi Szolgálat Rendvédelmi Szervek Védelmi Szolgálat Igazgatóság Bv. Főosztály munkatársainak igénybevételével. Az oktatásokon részletesen elemezik az FBÓ által a munkavégzéssel összefüggésben elkövethető bűncselekmények közül a Büntető Törvénykönyv ${ }^{43}$ 165. § Foglalkozás körében elkövetett veszélyeztetés, a 166. § Segítségnyújtás elmulasztása, a 265. § Minősített adattal visszaélés, a 282. § Bünpártolás, a 302. § Bántalmazás közfeladatot ellátó személy eljárásában és a 306. § Közfeladati helyzettel visszaélés búncselekmények törvényi tényállását, az egyes bűncselekmények súlyát, veszélyességét és a megelőzésük lehetőségeit. Az oktatás különösen népszerüvé vált az FBŐ-tagok körében, akik a hatósági vizsgára felkészítő tanfolyamon kaptak ugyan büntetőjogi alapismereteket, de ez esetben már a Btk. Különös részéből a szolgálati feladataikkal jellemzően öszszefüggő, a vonatkozó szabályozóban meghatározott bűncselekménytípusokat ele-

\footnotetext{
42 Jellemző bűncselekményi kategóriák, annak fogalma és jogi ismérvei, kényszerítő eszközök és alkalmazásuk, a büntetőjogi felelősségre vonás és annak akadályai, szolgálati okmányok vezetése, munka-, baleset- és tűzvédelem, elsősegélynyújtás, kriminalisztika, a büntetőeljárás alapjai, lőelmélet és lőgyakorlat stb.

43 2012. évi C. törvény a Büntető Törvénykönyvről.
} 
mezték. Az állományvédelmi oktatásokon tárgyalt bűncselekménytípusok mintegy 2/3-a új ismeretek megszerzését jelentette számukra, ugyanakkor a munkavállalói státuszú, még képzésre váró állomány pedig teljesen új ismereteket kapott a szolgálati feladatai ellátásához.

\section{Felszerelés}

A formaruházattal való központi ellátás rendjét (ruházati norma, tervezett viselési idő) alapvetően az FBŐ működéséről szóló BVOP ${ }^{44}$ utasítás határozza meg, amely ellátás a Bv. Holding Kft. ${ }^{45}$ útján, akár az egyedi méretnek megfelelő formaruházati termékek biztosításával valósul meg. A $10 \mathrm{M}$ e.r. gyakorló formaruházaton ${ }^{46}$ állományjelzésként a „Büntetés-végrehajtás Fegyveres Biztonsági Őrség” felirat szerepel, azon rendfokozati jelzés viselése nem megengedett. Az FBŐ karjelvénye szintén a formaruha részét képezi, azt a bal felkaron, a Bv. szerv hivatásos tagjának rendszeresített karjelvény helyén kell elhelyezni. A formaruha viselése a képzések és a szolgálatellátás során az FBÖ-állomány részére kötelező.

A már korábbiakban ismertetett fegyverzeti szakanyagokkal történő ellátás mind az alaphatározat, mind pedig az országos elrendelő határozat szerint a Bv. szerv feladata. A fegyveres biztonsági őr egyéni felszerelése bilincs, könnygáz, gumibot és lőfegyver kényszerítő eszköz, míg a Bv. szervnél rendszeresített lőfegyverek közül kizárólag maroklőfegyver biztosítása, azokkal történő ellátása kötelező. A fegyverszobákban a fegyverzeti alegységkészletből névre szólóan megjelölve és a többi fegyvertől elkülönítve kell tárolni az FBŐ létszáma szerinti, azzal megegyező darabszámú szolgálati jelvényt, felszerelést és fegyverkészletet. További kötelezettség, hogy azok sorozatszámát az adott szerv őrségutasításában is fel kell tüntetni.

\section{Szolgálatellátás}

Alaptézis, hogy az FBŐ tagjainak munkavégzését, szolgálatellátását úgykell megszervezni, hogy - tekintettel a Bv. szervezetről szóló 1995. évi CVII. törvényben (Sztv.) meghatározott feladatok ellátására - hivatali, valamint azon kívüli időszakban is a megfelelő létszámban rendelkezésre álljanak. Az FBŐ-tagok őrutasításban rögzített szolgálatellátását, a követelmények és feladatok végrehajtását, a havi és napi te-

\footnotetext{
${ }_{44}$ Az említett BVOP utasítás a fegyveres biztonsági őrség Múködési és Szolgálati Szabályzatának kiadásáról szóló a 27/1998. (VI. 10.) BM rendelet alapján, a Bv. szerv múködési, múködtetési szabályainak figyelembevételével készült el.

45 Bővebben: www.bvholdingkft.hu/

46 Ruházat: www.bvhwebshop.hu/labbelik-164/ruhazat-178
} 
vékenység tervezését és teljesítését a Robotzsaru ${ }^{47}$ rendszerben és a meghatározott szolgálati okmányokban ${ }^{48}$ is rögzíteni kell.

Az FBŐ tagjai, szolgálatukat az adott Bv. szervek Biztonsági Osztályai által készített vezénylési terv alapján látják el. Szolgálatba csak érvényes hatósági vizsgával rendelkező fegyveres biztonsági őr vezényelhető, akinek feladata az elrendelő határozatban előirt, az őrszolgálati okmányokban szereplő felállítási helyeken és járőrútirányokon őrzési feladat végrehajtása, amit a rendelkezésre álló létszám függvényében a személy-, illetve gépjármű bejáró kapukban, a bástyafalakon levő tornyokban, illetve járőr útirányokon a fogvatartottakkal való közvetlen érintkezés nélkül teljesítenek az adott Bv. szerv szükséglete szerint. A biztonsági szakterület napi szolgálattervezési okmányában a napi szolgálatra beosztott FBŐ-állományt a hivatásos állománytól eltérően kell jelölni. Az őrségparancsnoki feladatokat az egyes Bv. szerveknél az ORFK FBŐ-nél alkalmazott mintára tekintettel a Biztonsági Osztályok vezetői mint őrségparancsnok-helyettesek hajtják végre. Az őrparancsnok napi irányítási, eligazító, ellenőrző, beszámoltató és a felszereléseket kiadó, visszavételező tevékenységét pedig a mindenkor szolgálatban levő biztonsági tisztek teljesítik.

A Bv. szervek vezetői jellemzően pozitívan értékelik az FBŐ-állomány tevékenységét. Általános tapasztalat, hogy a felvett, kiképzett FBŐ-tagok - az esetenkénti nehézségeket követően - jól integrálódtak az adott Bv. szerv szolgálatellátási rendszerébe, beilleszkedtek a közösségekbe, a feladataikat lelkiismeretesen végzik. A tevékenység rendszeresítésétől a tanulmány elkészítéséig eltelt időszak alatt egy esetben fordult elő rendkívüli esemény, egy töltés-ürítés közbeni véletlen lövés, amelynél azonban sem személyi sérülés, sem pedig anyagi kár nem keletkezett, ugyanakkor egy esetben egy még tanfolyamot nem végzett, tanuló szolgálatot ellátó munkavállaló a járőrtevékenység végzése közben 12 okostelefont tartalmazó elrejtett csomagot fedezett fel éber szolgálatellátásával. ${ }^{49}$

\section{Az FBő jövőbeni alkalmazásának egyes lehetôségei}

Az FBŐ-állomány rendszerbe állításának kedvező szolgálati tapasztalataira tekintettel jogszerűen vetődik fel az FBŐ tevékenységi kör bővítésének, a Bv. hivatásos állományú tagjai további tehermentesítésének, így a személyi szabadságukban korlátozott személyekkel kapcsolatos - jelenleg még korlátozás alá eső - feladatok ellá-

47 Robotzsaru integrált ügyviteli, ügyfeldolgozó és elektronikus iratkezelő rendszer.

48 Szolgálati napló, szolgálati előjegyzés, eseménynapló, ellenőrzési napló, amelyet a területi rendőri szerv biztosít, fegyver- és lőszernyilvántartás, őrutasítás és védelmi vázlat, őrhelytáblázat, riadóterv, együttműködési terv, nyílt parancs minta, belépést engedélyezni jogosultak bélyegzôvel és aláírásával ellátott belépési engedély- és pecsétmintái, azoknak a személyeknek az adatai, akik jogosultak a lezárt raktár vagy más őrzött helyiség kinyitására, elrendelő határozat, szolgálati okmányokat jóváhagyó határozat, őrségutasítás egy-egy példánya.

49 Teremi Zoltán ny. r. ezredes BV FBŐ őrségparancsnokkal a BVOP-n 2021. 03. 23-án készített személyes interjú alapján. 
tásának kérdésköre. A bővítés lehetősége természetesen számos szakmai tartalmú kérdést vet fel, amelyekre a jelen fejezetben igyekszem a Bv. őrségparancsnokával történő szakmai egyeztetés alapján, vele egyetértve választ adni.

$\mathrm{Az}$ egyik legkisebb változtatási igényű alkalmazási lehetőségként jöhet szóba az FBŐ tagjának egyéb biztonsági feladatokba való bevonása. A fegyveres biztonsági őrségről, a természetvédelmi és a mezei őrszolgálatról szóló 1997. évi CLIX. törvény (FBỐ törvény) és a fegyveres biztonsági őrség Szolgálati és Működési Szabályzatának kiadásáról szóló 27/1998. (VI. 10.) BM rendelet (Rendelet) előírásai szerint - alapesetben -, csak az őrutasítás szerinti feladat(ok) végrehajtására lehet szolgálatba vezényelni. Ugyanakkor az FBŐ tagja - szükség esetén, eseti jelleggel - az őrutasításban nem szabályozott feladat(ok) végrehajtására is alkalmazható, amelyek ellátása nem veszélyeztetheti az alapszolgálat ellátását és ezekhez az őrség szolgálati felszerelése sem használható. ${ }^{50}$ Ilyen feladattal tehát csak a szolgálati okmányokban elrendelt alapszolgálat ellátásán felül bízható meg, és annak végrehajtásához sem a szolgálati fegyvere, sem az egyéb kényszerítő eszközei nem adhatók ki. Ezen feltételeknek megfelelő alkalmazási terület lehet például az elektronikus megfigyelési eszközök kezelése, a monitorfigyelési tevékenység ellátása. Ennél a bővítési lehetőségnél megfogalmazott tevékenységek a jelenleg hatályos jogszabályi környezetben az alaptevékenység sérülése nélkül is végezhetők, azok végzéséhez jogszabály-változtatás kezdeményezése, a hatályos őrszolgálati okmányok módosítása, illetve az FBÖ létszámnövelése sem szükséges.

További alkalmazási területként merülhet fel az Sztv. alapján, az FBŐ-állomány részére biztosított lehetőségek közül eddig igénybe nem vett alkalmazási formákba, így az Sztv. 10. § (3a) bekezdésének d) pontjában ${ }^{51}$ jelölt területőrzési és az e) pontjában ${ }^{52}$ meghatározott foglalkoztatás biztosítási tevékenységek ellátásába történő bevonásának lehetősége.

Míg az FBŐ alaptevékenységeként az ORFK határozataiban megjelölt földrajzi címeken található területek (értsd: a Bv. szerv objektumainak) őrzése fogalmazható meg, addig az Sztv. „a bv. szervek határán kívül elhelyezkedő területen” történő őrzést érti területőrzésen, a Bv. szervek anyagi javai vagy a fogvatartottak őrzése érdekében. Ez az ellentmondás a Bv. szervek anyagi javainak őrzése vonatkozásában feloldható, ugyanakkor a fogvatartottak őrzése vonatkozásában már nem, ugyanis míg a Rendelet 31/A. §-a lehetőséget teremt a rendvédelmi szervek keretében müködtetett FBŐ-k esetében a személyőrző és -kísérő őri feladatok ellátására, addig az ORFK határozatai a Bv. szervek vonatkozásában csak az objektumőrzési tevékenységet rendelik el. Ugyanakkor az Sztv. szerinti ${ }^{53}$ fogvatartotti foglalkoztatás biztosítási

\footnotetext{
27/1998. (VI. 10.) BM rendelet a fegyveres biztonsági őrség Müködési és Szolgálati Szabályzatának kiadásáról 5. §.

1995. évi CVII. törvény a büntetés-végrehajtási szervezetről 10. § (3a) d) területőrzés a bv. szervek határán kívül elhelyezkedő területen a bv. szervek anyagi javainak vagy az ott-tartózkodó fogvatartottak őrzése érdekében.

1995. évi CVII. törvény 10. § (3a) e) fogvatartotti foglalkoztatás biztosítása a bv. szervek területén belül vagy kívül.

3 1995. évi CVII. törvény 10. § (3a) bekezdés e) pont.
} 
tevékenység végzése - a már említett szabályozás értelmében - ez esetben sem végezhetö. $^{54}$

Szintén lényeges és meg nem kerülhető körülmény, hogy az FBŐ tagjainak felkészítésére jóváhagyott hatályos „Képzési Program” a fogvatartottak őrzése vonatkozásában jelenleg csak kettő óra elméleti és további kettő óra gyakorlati képzési ismeretet tartalmaz. Ez esetben tehát a program módosítására, a jelenlegi képzések szakirányú tartalommal történő kiegészítésére, valamint a meglévőkre ráépülő szakmai tartalmú tanfolyami felkészítések lebonyolítására van szükség. Ugyanakkor a „Képzési Program” kibővítésén túl kezdeményezni szükséges az ORFK elrendelő határozat módosítását az őrzendő objektumok és az FBŐ-létszám emelése vonatkozásában, illetőleg a hatályos őrszolgálati okmányok átdolgozása is indokolt. Jogszabály-változtatás kezdeményezése az előző lehetőséghez hasonlóan ebben az esetben sem indokolt.

Harmadik lehetőségként jelölöm az FBÖ-állomány számára új, a jogszabály által eddig nem említett alkalmazási formákban, így a fogvatartottakkal kapcsolatos előállítási és szállítási tevékenységek ellátásában történő alkalmazását. Tényként állapítom meg, hogy az Sztv. vonatkozó pontjai ${ }^{55}$ nem tartalmaznak az ennek a tevékenységnek a végzésére felhatalmazó rendelkezést, és a Szakutasítás ${ }^{56}$ is biztonsági felügyelőket jelöl ki e tevékenységek elvégzésére, valamint hogy a „Képzési Program” sem tartalmazza az előállítással, illetve szállítással kapcsolatos részletes és elsajátítható ismereteket. Ugyanakkor az is kijelenthető, hogy az előállítási és szállítási tevékenységek végzése a jelenleg rendszeresített FBŐ-létszámmal nem, csak az állománytábla szerinti létszám megnövelésével, a vonatkozó jogszabály, az ORFK elrendelő határozat és a belső szabályozók (Szakutasítás, őrzési dokumentumok), valamint a képzési tevékenység és tananyag módosításával biztosítható. ${ }^{57}$

Mindhárom tevékenységi kör bővítési elképzelése kapcsán markánsan jelen lévő további kérdéskör - különösen a Bv. hivatásos állományú testületi tagjainak iskolarendszerű felkészítésére, annak időbeliségére és szakmai tartamára -, hogy az FBŐtagok tanfolyami felkészítése és intézkedési jogosultságai vajon alkalmassá teszik-e őket a fogvatartottakkal való közvetlen munkavégzésre, a munkakörrel járó intézkedések megtételére.

\footnotetext{
54 Megjegyzés: a „Képzési Program” V. modulja 2 óra elméleti és 2 óra gyakorlati képzést biztosít ebben a témában, de ez az óramennyiség még az alapismereti szint elérését is kérdésessé teszi, a jártasság szint elérését pedig kizárja. 1995. évi CVII. törvény 10. § (3a) bekezdés $a)-e$ ) pont.

56 A büntetés-végrehajtási szervezet Biztonsági Szabályzatának kiadásáról szóló 26/2015. (III. 31.) OP szakutasítás, amelyet 2021. február 1-jén módosítottak (és hatályon kívül helyeztek) a büntetés-végrehajtási szervezet Biztonsági Szabályzatáról szóló 72/2020. (XII. 23.) BVOP utasítás kiadásával.

57 Fontosnak tartom megjegyezni, hogy ezt a tevékenységet természetesen nem önállóan, hanem egy hivatásos állományú, az előállítást végző felügyelő szakmai irányításával láthatná el.
} 


\section{Befejezés, avagy jó ötlet az FBó a húvösön?}

A majd százéves történelmi hagyományokkal rendelkező FBŐ Bv. szervezetében történő 2019-es létrehozása különösen forradalmi jellegűnek tekinthető, megkockáztatom annak kijelentését, hogy az ezeréves tradíciókkal rendelkező börtönvilág nyitását, az innovatív törekvések hajnalát is szimbolizálhatja. Annak tényét, hogy még a legnagyobb történetiséggel rendelkező szervezeteknek is meg kell tudni újulni és fel kell ismerniük a változás, a változtatás igényét, nyitottnak kell lenniük a jelenkor történéseire, az újszerű megoldásokra.

A Bv. FBÖ létrehozása korántsem indult zökkenőmentesen, és múködtetése is számos olyan problémát hozott a felszínre, amelyek megoldása szintén újszerű megoldásokat követelt. Ugyanakkor az eddig eltelt rövid alkalmazási időszak tapasztalatai is azt mutatják, hogy létrehozása jó döntésnek minősült, beváltotta a hozzá füzött vezetői elvárásokat, és működésének kiterjesztése további előnyökkel is járhat.

\section{FELHASZNÁLT IRODALOM}

Boda József (szerk.): Rendészettudományi Szaklexikon. Budapest, Dialóg Campus, 2019.

Christián László - Erdős Ákos: Vészharang és jubileum? A rendészeti felsőoktatás kilátásai, a tisztjelöltek toborzásának és életpályára állításának nehézségei. Belügyi Szemle, 68. (2020), 12. 11-42. Online: https://doi.org/10.38146/BSZ.2020.12.1

Christián László - Lippai Zsolt: Kakukktojás vagy új rendészeti alappillér. In Csaba Zágon - Zsámbokiné Ficskovszky Ágnes: „Tehetség, szorgalom, hivatás”. Budapest, Magyar Rendészettudományi Társaság Vám- és Pénzügyőri Tagozat, 2021. 17-30. Online: https://doi.org/10.37372/ mrttvpt.2021.1.1

Lippai Zsolt: Az elmosódó határvonalak margójára. Szakmai Szemle, 21. (2021), 1. 150-165. Lőrincz József - Mezey Barna: A magyar börtönügy története. Budapest, Dialóg Campus, 2019.

Várkonyi Zsolt Kristóf (főszerk.): Börtönstatisztikai Szemle, 2020. Online: https://bv.gov.hu/sites/ default/files/Bortonstatisztikai_Szemle_2020.pdf

Várkonyi Zsolt Kristóf (főszerk.): Ezer éves múltunk. A büntetés-végrehajtás az igazság védelmében. Budapest, BVOP, 2021.

\section{Jogi források}

1995. évi CVII. törvény a büntetés-végrehajtási szervezetről

1997. évi CLIX. törvény a fegyveres biztonsági őrségről, a természetvédelmi és a mezei őrszolgálatról

2012. évi I. törvény a munka törvénykönyvéről

2012. évi C. törvény a Büntető Törvénykönyvről

27/1998. (VI. 10.) BM rendelet a fegyveres biztonsági őrség Múködési és Szolgálati Szabályzatának kiadásáról

26/2015. (III. 31.) OP szakutasítás a büntetés-végrehajtási szervezet Biztonsági Szabályzatának kiadásáról (2021. február 1-jétől hatályon kívül) 
1/2020. (II. 21.) BVOP utasítás a büntetés-végrehajtási szervezetben múködtetett fegyveres biztonsági őrségről

72/2020. (XII. 23.) BVOP utasítás a büntetés-végrehajtási szervezet Biztonsági Szabályzatáról (2021. február 1-jétől hatályos)

\title{
Internetes források
}

Büntetés-végrehajtás. Az igazság védelmében: BV szervezet. Online: https://bv.gov.hu/hu/ bv-szervezet-ismerteto

BV. Holding: Ruházat. Online: www.bvhwebshop.hu/labbelik-164/ruhazat-178

Gyere a hűvösre: Fegyveres biztonsági ôr. Online: https://gyereahuvosre.hu/jobs/fegyveres-biztonsagi-or-14/

Magyarországi Fegyveres Biztonsági Őrök: A szervezet múltja. Online: https://mfbosze.hu/azfbo-multja/

\section{ABSTRACT}

\section{The Armed Security Guard of the Hungarian Prison Service}

\author{
Zsolt LIPPAI
}

The armed security guard and its predecessor organisations look back on a history of nearly a century. It is the only special armed organisation in Hungary, which does not belong to the law enforcement agencies or the army, its nature operates under civilian, strictly hierarchical and controlled rules. Its cross-system function and mission for which it was created is unchanged. Nowadays, the armed security guard, with a total number of nearly 7,000 people, protects activities, facilities and shipments that are extremely important for the operation of the state and the supply of the population.

Studying the organisations of the armed security guard and its predecessor, it can be stated that while in international and domestic relations, a number of researches deal with the history of critical infrastructure protection, the historical processing of the Hungarian organisational antecedents has not yet taken place. In my study, as a gap-filling work, I present the creation and current operation of the armed security guard of the Hungarian Prison Service.

Keywords: Hungarian Prison Service, armed security guard 